10.4274/tjps.46793

Research Article

\title{
A Novel Genotyping Method for Detection of Muscarinic Receptor M1 Gene rs2067477 Polymorphism and Its Genotype/Allele Frequencies in a Turkish Population
}

\author{
Muskarinik Reseptör M1 Geni rs2067477 Polimorfizminin Tespiti Icin Yeni Bir \\ Genotipleme Metodu ve Türk Şizofreni Hastalarındaki Genotip/Allel Frekansları
}

\section{Short Title: Novel Genotyping Assay for Muscarinic Receptor M1}

Kısa Başlık: Muskarinik Reseptör M1 için Yeni Genotipleme Yöntemi

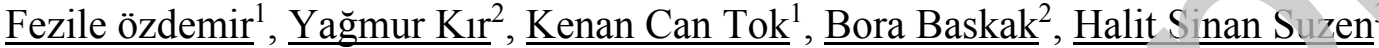

${ }^{1}$ Ankara University, Institute of Forensic Sciences, Department of Forensic Toxicology, Ankara

${ }^{2}$ Ankara University, School of Medicine, Department of Psychiatry, Ankara

${ }^{3}$ Ankara University, Faculty of Pharmacy, Department of Pharmaceutical Toxicology, Ankara

\begin{abstract}
Objective: Gene variation in the cholinergic muscarinic receptor 1 (CHRM1) has a potential to become one of candidate biomarker in the development of several disorders and also drug response. In this study, a novel PCR- RFLP assay was developed to determine the C to A single nucleotide polymorphism at position 267 in the CHRM1 gene.

Materials \& Methods: A new reverse primer and a mismatched forward primer were designed to obtain $125 \mathrm{bp}$ PCR products. PCR products were then digested with the Hae III restriction enzyme to detect the $\mathrm{r} 2067477$ polymorphism that comprises of $\mathrm{C}$ to A base change. The developed novel assay was tested in 51 Turkish schizophrenia patients.

Results: Genotyping assay was successfully performed in patients with schizophrenia in order to confirm the accuracy and validity of this method. The frequency of CC, CA and AA genotypes were found as $72.5 \%, 25.5 \%$ and $2 \%$, respectively. On the basis of this data, the allele frequency of $\mathrm{C}$ was 0.85 and the allele frequency for A was 0.15 .

Conclusion: The suggested genotyping assay is practical for screening the CHRM1 C267A polymorphism in pharmacogenetic studies. The present polymorphism may use as a candidate biomarker to find out genetic susceptibility to related diseases' and may contribute to the implementation of individualized drug therapy for M1 related diseases.

Keywords: CHRM1, C267A, Turkish, Schizophrenia, PCR-RFLP

ÖZ

A maç: Kolinerjik muskarinik reseptör 1'deki (CHRMI) gen varyasyonu, çeşitli bozuklukların ve ayrıca ilaç yanıtının gelişiminde aday biyogöstergelerden biri olma potansiyeline sahiptir.

Bu çalışmada, CHRM1 geninde 267. pozisyondaki C'den A'ya olan tek nükleotid polimorfizmini belirlemek için yeni bir PCR-RFLP analizi geliştirilmiştir.

Gereç ve Yöntemler: 125 bp PCR ürünlerini elde etmek için yeni bir reverse primer ve uyumsuz bir forward primer tasarlanmıștır. PCR ürünleri daha sonra C'den A'ya olan baz değişikliğini içeren rs2067477 polimorfizmini tespit etmek için Hae III restriksiyon enzimi ile kesilmiştir. Geliştirilen yeni analiz, 51 Türk Şizofreni hastasında test edilmiştir.
\end{abstract}


Bulgular: Bu yöntemin doğruluğunu ve geçerliliğini onaylamak için genotipleme analizi, şizofreni hastalarında başarıyla uygulanmıştır. CC, CA ve AA genotiplerinin sıklığı sirasıla $\% 72.5, \% 25.5$ ve\% 2 olarak bulundu. Bu verilere dayanarak, C alel frekansı 0.85 ve A alel için frekans 0.15 idi.

Sonuç: Önerilen genotipleme deneyi, farmakogenetik çalışmalarda CHRM1 C267A polimorfizminin belirlenmesi için pratiktir. Bu polimorfizm, ilgili hastalıklara karşı genetik duyarlılığ 1 göstermek için aday bir biyogösterge olarak kullanılabilir ve M1 ile ilgili hastalıklar için bireyselleştirilmiş ilaç tedavisinin uygulanmasına katkıda bulunabilir. Anahtar Kelimeler: CHRM1, C267A, Türk, Şizofreni, PCR-RFLP

Halit Sinan Suzen, Ankara University, Faculty of Pharmacy, Department of Pharmaceutical Toxicology, Ankara

suzen@ankara.edu.tr

+905333453799

0000-0003-1779-5850

20.08.2019

07.11 .2019 


\section{INTRODUCTION}

The prenatal and perinatal risks, negative early life events and genetic predisposition may cause neurodevelopmental alterations and sensitize the dopamine system in the brain; the presence of these factors may contribute to development of schizophrenia. ${ }^{1,2}$ The prevalence of schizophrenia varies from 3 to 7 per 1000 in worldwide and the average lifetime prevalence is $4 / 1000$ while the lifetime risk is 7.2 per $1000 .{ }^{3,4}$ However, the studies about the prevalence of schizophrenia have shown that the disorder differs in all societies and that could vary according to the characteristics of the society. ${ }^{5,6} \mathrm{~A}$ systematic review based on a limited number of general population survey conducted in Turkey showed that the prevalence of schizophrenia, was 8.9 in $1000 .^{7}$

The risk of schizophrenia is $10 \%$ for first degree relative while $40 \%$ for child if both parents have schizophrenia. ${ }^{8}$ In addition to heredity in the development of this disease, the gene differences involved in the pharmacokinetics and pharmacodynamics of the drugs which are used in the treatment of schizophrenia also play a major role in treatment, response and adverse drug reactions.

Antipsychotic drugs used in the treatment of schizophrenia such as clozapine (CLZ) and olanzapine have been found to be antagonistic to muscarinic receptors. ${ }^{9}$ Clozapine is prescribed especially in treatment resistant schizophrenia patients and it is a weak muscarinic receptor 1 (M1) agonist while its active metabolite, N-desmethylclozapine (NCLZ), is a potent M1 agonist receptor. ${ }^{9}$ In addition, M1 receptor agonist DCLZ plays an important role in determining the clinical effects and pharmacotherapy in the treatment of psychotic disorders. Studies have also pointed out that a decreased density of M1 receptors particularly in the neocortical regions was associated with schizophrenia. ${ }^{10}$ Similarly, some studies showed that reduced M1 receptor mRNA level in brain samples of schizophrenia patients. ${ }^{11}$ Considering all of these, M1 receptor is one of the important targets in the development and also treatment of schizophrenia.

There are five types of cholinergic muscarinic receptors designated as M1 to M5. Among these, the Muscarinic receptor 1 (M1) is mostly located in the nervous system. M1 is typically found in the parasympathetic ganglia, cortical and hippocampal regions of brain, less in airway epithelial cells and is involved in cognitive functions such as learning and memory, as well as regulation of cardiac contraction. ${ }^{12,13}$ The M1 is encoded by the CHRM1 gene located on chromosome 11q12.3. There are fifteen single nucleotide polymorphisms (SNPs) in CHRM1 gene region, one of them is the C267A (rs2067477) base change. This polymorphism is a silent mutation which is a transversion of cytosine $(\mathrm{C})$ to adenine $(\mathrm{A})$ at position 267 on the $C H R M 1$ gene region. It is in wobble site of the codon (GG $\rightarrow$ $\rightarrow$ GGA $)$ so the protein sequence is preserved. ${ }^{13,14}$

In short, the determination of the SNPs in the gene regions which are potentially involved in schizophrenia, are important because they could affect the disease susceptibility, cognitive performance, drug response or adverse drug reactions. The Polymerase Chain ReactionRestriction Fragment Length Polymorphism (PCR-RFLP) assay is one of the most common, simple, effective, fast and inexpensive method used to determine the SNPs. Thus, our aim was to develop a novel PCR- RFLP method for genotyping CHRM1 C267A polymorphism.

Subsequently, the developed PCR-RFLP assay was performed for validation of the method and determination of genotype and allele frequencies in Turkish patients with schizophrenia.

\section{MATERIALS \& METHODS}

\section{Study Subjects and DNA Isolation}

Whole blood samples were obtained from 51 Turkish schizophrenia consecutive outpatients who admitted to Ankara University Medical Faculty Psychiatry Department and diagnosed with Diagnostic and Statistical Manual of Mental Disorders, fourth edition ${ }^{15}$ between October 
2016- April 2018. Inclusion criteria were: age between 18- 65 and having signed the written informed consent. Patients with additional psychiatric diagnosis as well as general medical comorbidity were excluded. An informed consent was obtained from all subjects and the protocol was approved by the Research Ethics Committee of Medical Faculty, Ankara University. Genomic DNA was extracted with high salt method from peripheral blood of 51 subjects. ${ }^{16}$ The absorbance level of DNA samples for 260 and $280 \mathrm{~nm}$ was detected with spectrophotometric analysis and the purity of the samples was between 1.7-2.0.

\section{PCR Primers and Conditions}

The sequence data of C267A (rs2067477) polymorphism in human CHRM1 gene region was obtained from NCBI website (http://www.ncbi.nlm.nih.gov) and the new primers were designed as follows based on the published sequence: forward primer: 5 '-

TACTTCCTGCTGAGCCTAGCC-3', reverse pimer: 5'GCCAGCCAGAGGTCACAAGCC-3'. The PCR reaction was carried out in a volume of 25 $\mu$, which was containing 10x PCR buffer (Amplicon, Denmark; containing $10 \times$ Ammonium and $15 \mathrm{mM} \mathrm{Mg}$ ), $1.1 \mathrm{mM} \mathrm{MgCl}_{2}, 0.1 \mathrm{mM}$ dNTP, 10 pmol from each primers, $1.5 \mu \mathrm{LMSO}$, $0.45 \mathrm{U}$ of Taq DNA polymerase (Amplicon, Denmark), approximately $100 \mathrm{ng}$ of genomic DNA and distilled water to complete final volume to $25 \mu \mathrm{l}$. One hundred twenty five (125) bp PCR product was obtained by using the following PCR cycling conditions; the initial denaturation at $94{ }^{\circ} \mathrm{C}$ for $3 \mathrm{~min}$, followed by 3 graded 30 cycles were performed which are denaturation at $94{ }^{\circ} \mathrm{C}$ for $30 \mathrm{sec}$, annealing for $30 \mathrm{sec}$ at $59{ }^{\circ} \mathrm{C}$ and elongation at $72{ }^{\circ} \mathrm{C}$ for 45 sec. In the end, final extension for $5 \mathrm{~min}$ at $72^{\circ} \mathrm{C}$ was carried out. The PCR products $(125 \mathrm{bp})$ were visualized under ultraviolet illuminator on a $1 \%$ agarose gel which was stained with ethidium bromide.

\section{RFLP Conditions}

The RFLP was carried out in a $20 \mu \mathrm{l}$ volume mixture consisting of $2 \mu 1$ 10x Buffer, $10 \mathrm{U}$ Hae $I I I$ enzyme (New England Biolabs, USA), $10 \mu \mathrm{l}$ PCR product and $7 \mu 1$ distilled $\mathrm{H}_{2} \mathrm{O}$. The reactions were incubated at $37^{\circ} \mathrm{C}$ overnight and the digested products were visualized under an UV transilluminator after they were electrophoresed on 3\% agarose gel containing ethidium bromide for 1 hour. The digested RFLP products were obtained for wild-type genotype while there were undigested RFLP products for mutant genotype on the agarose gel. To further assess the reliability of the presented assay, PCR product of each different genotype was verified by direct sequencing using the same set of primers.

\section{Statistical Analysis}

Allele and genotype frequencies were calculated by genotype counting method. The observed genotype frequencies of CHRM1 C267A were compared with the expected frequencies according to Hardy-Weinberg equilibrium. Obtained data were compared with previously reported representative data in other ethnic groups. Differences in allele frequencies between schizophrenic groups were tested by Pearson's Chi-square Test and while a $\mathrm{p}$ value $<0.05$ was considered statistically significant.

\section{RESULTS}

A novel PCR-RFLP assay was designed to detect C267A SNP in CHRM1 gene region in schizophrenic patients with schizophrenia. We also evaluated the accuracy and validity of this novel method. New primers were designed and the PCR products were digested with Hae III restriction enzyme for determination of the variant genotypes. Schematic illustration of the assay is given in Figure 1. 

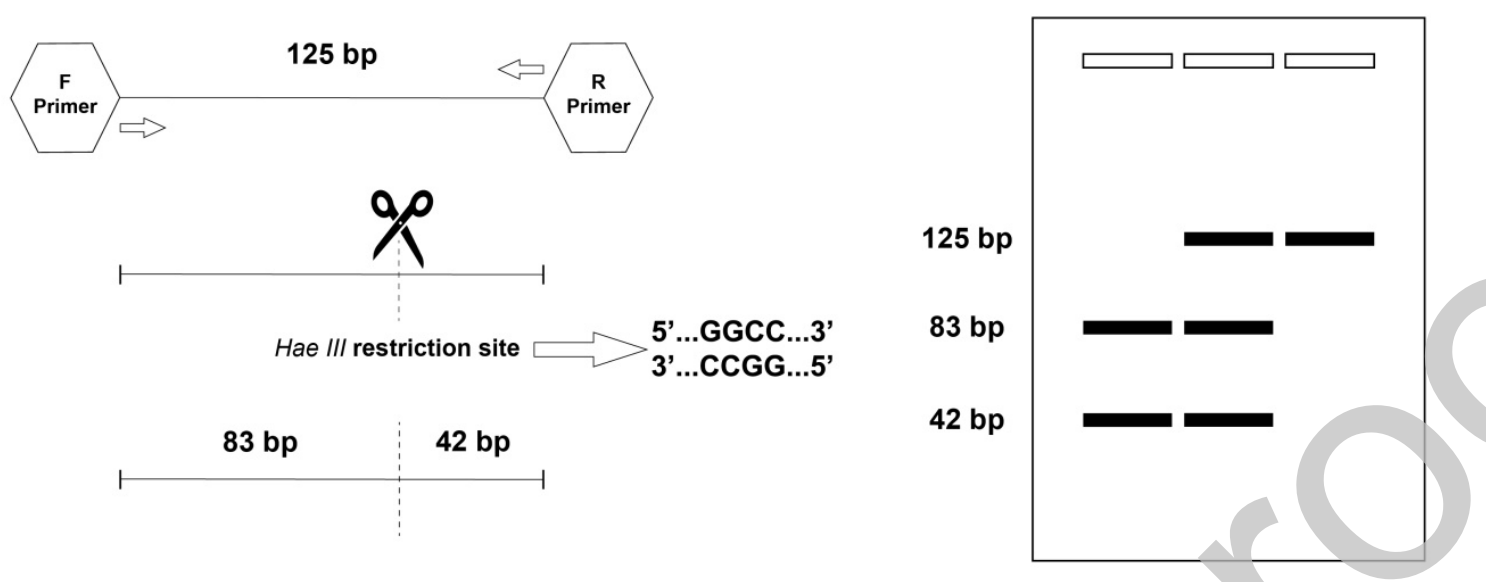

Figure 1. Diagrammatic representations of recognition sites of Hae III enzyme and the schematic illustration of the restriction fragments for each genotype of CHRM C267A SNP. The previous genotyping method for rs2067477 by Liao et al., could not perfectly apply to analyze this SNP due to the difficulties in the finding primer sites. This method did also not include any information about PCR product fragments, PCR conditions and base pairs of the restriction fragments for genotyping. ${ }^{17}$ In the present study, a novel genotyping assay was developed and successfully performed by utilizing a reverse primer and mismatch forward primer, which are explained above. As shown in Figure 2, the underlined A (adenine base) is the mismatched base in the forward primer which was replaced with the ancestral base $\mathrm{G}$ (Guanine base) to eliminate the recognition site of Hae III restriction enzyme (GG $\nabla$ CC) in the primer binding site. This was also confirmed by sequencing (data not shown).

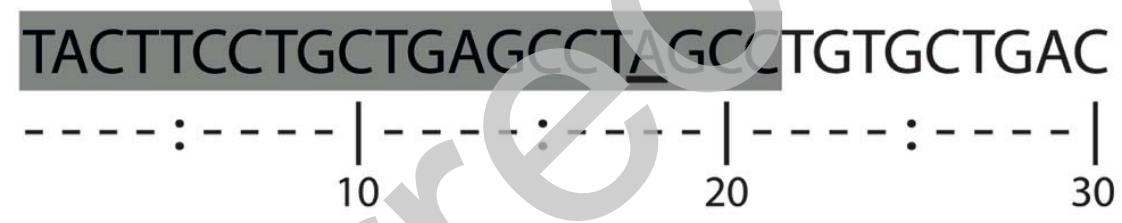

\section{CTCATCATCGGTACCTTCTCCATGAACCTC}

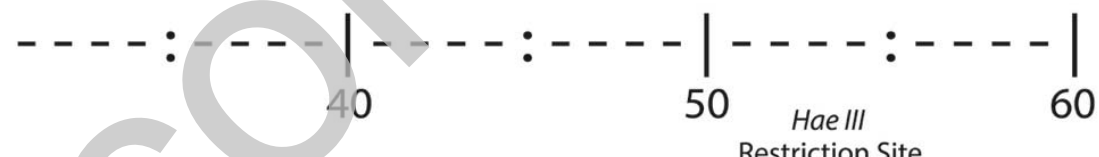

TATACCACGTACCTGCTCATGGGCCACTGG

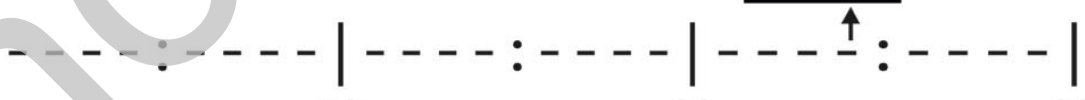

70

80

GCTCTGGGCACGCTGGCTTGTGACCTCTGG

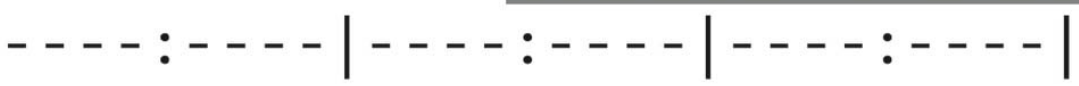

100

110

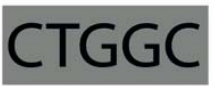

---- : 
Figure 2. Restriction analysis of CHRMI with Hae III endonuclease. Forward and reverse primers are highlighted as grey. The mismatch base (A), which is used to eliminate the recognition site of Hae III in forward primer, is underlined. Hae III recognition site is depicted by underline in the middle of the CHRM1 sequence. This recognition site also includes rs2067477 SNP, which is depicted with capital and bold letter in recognition site (C). In case of ancestral C allele at position 267 of CHRM1 gene 83 bp and $42 \mathrm{bp}$ DNA fragments obtained, after Hae III digestion. Conversely, no digestion site for Hae III endonuclease is found, when $\mathrm{C}$ allele is replaced by A allele at position 267 which giving one fragment of 125 bp.

The individuals with CC genotype (wild-type) yielded two bands of $83 \mathrm{bp}$ and $42 \mathrm{bp}$, whil the individuals with AA genotype (mutant type) gave undigested band (125 bp) on the 4\% agarose gel. Agarose gel electrophoresis results of the RFLP products on 3\% agarose gel are given in Figure 3.

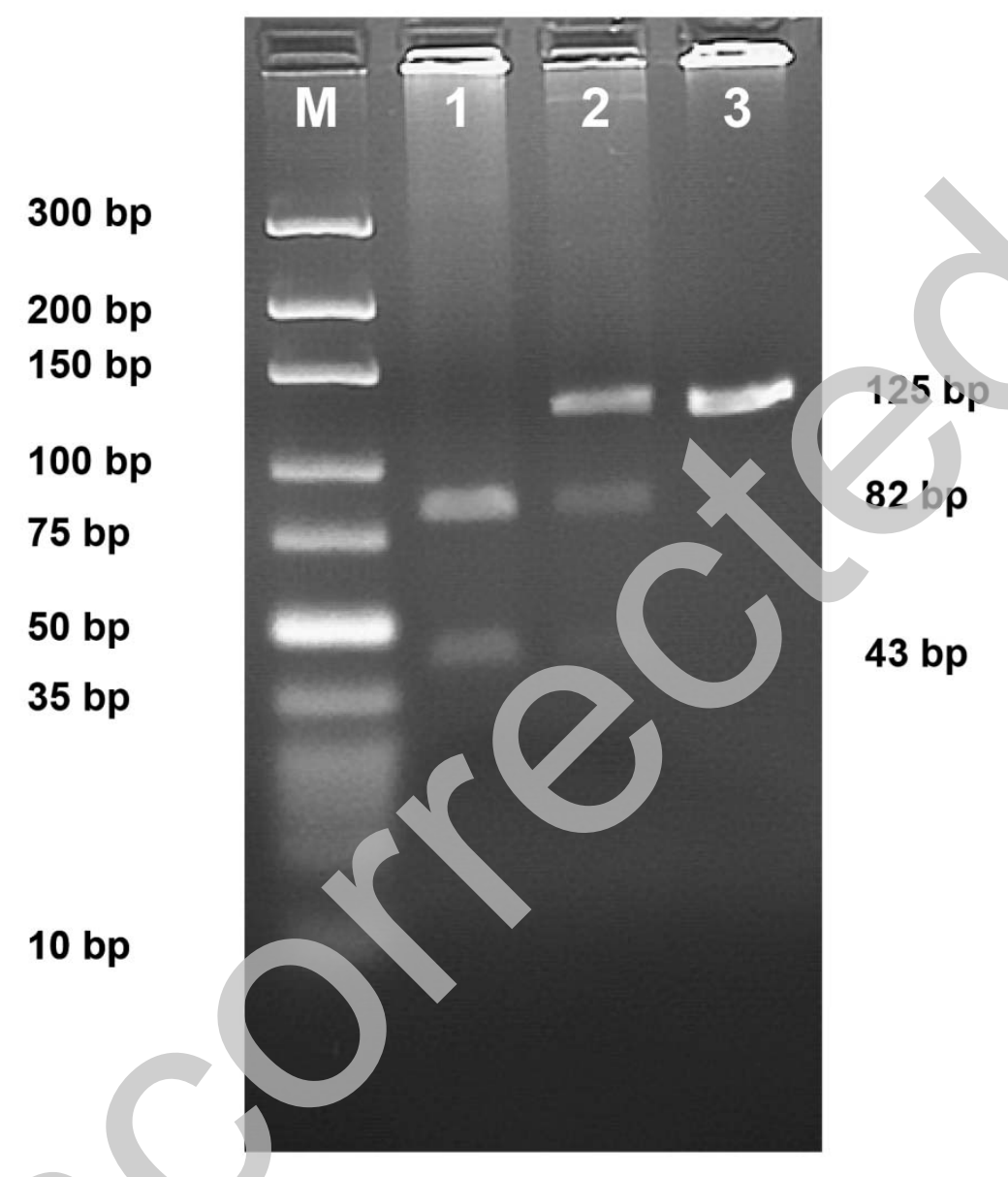

Figure 3. Agarose gel electrophoresis demonstrated the expected RFLP product sizes. The results shown in 1,2,3 were in the same order as in Figure 1. (M: Thermo Fisher Scientific GeneRuler Ultra Low Range DNA Ladder Marker (10 -300 bp, SM1211). 1: CC genotype, 2: CA genotype and 3: AA genotype).

One sample of each different genotype PCR products were sequenced for confirm the expected sequence of each genotype and the obtained data was consistent with our findings. The sequencing results of three genotypes are given below in Figure 4. PCR products of each different genotype sequencing result precisely demonstrated that confirmation the reliability of our novel assay. 

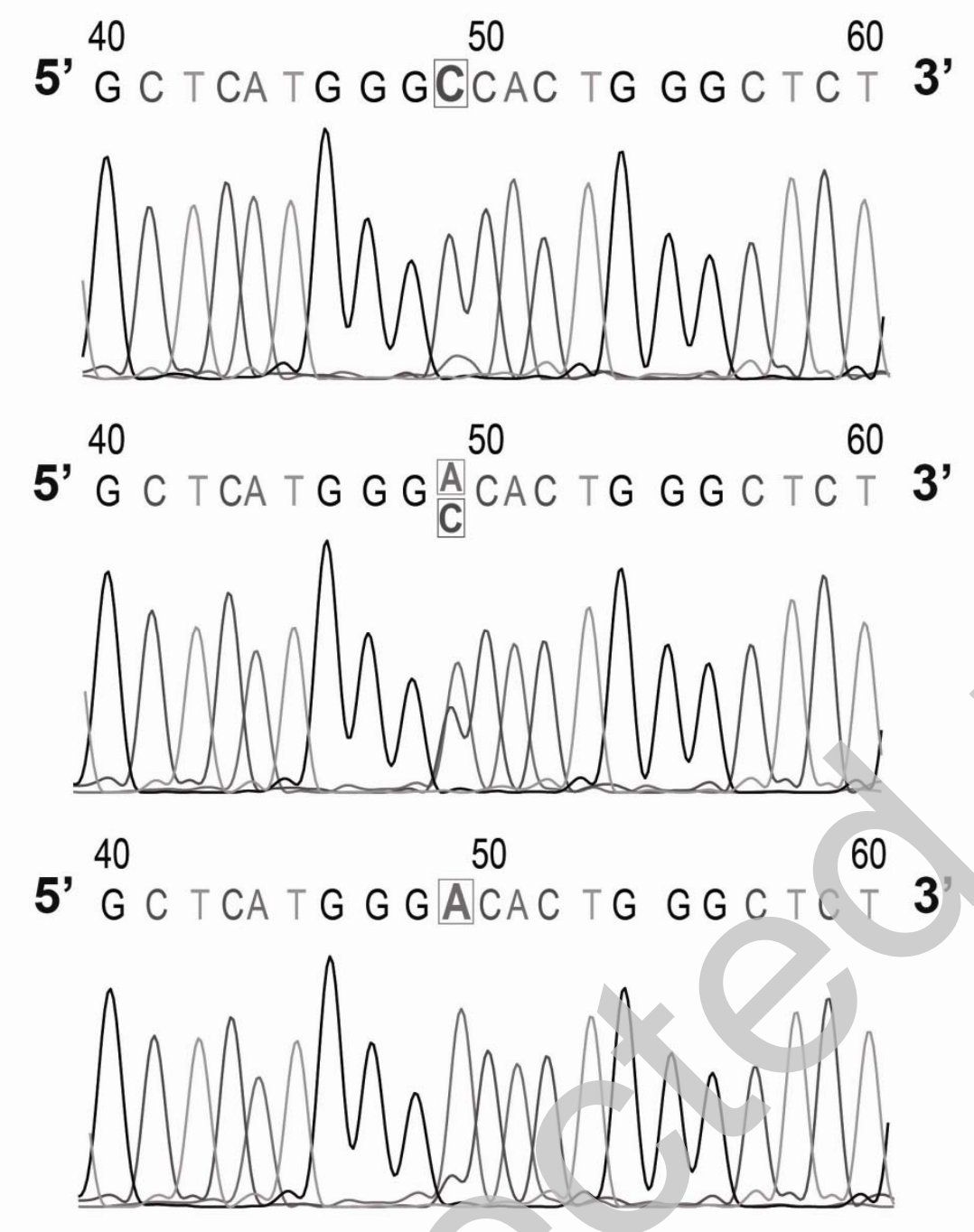

Figure 4. Examples of DNA sequencing of the polymerase chain reaction product of the CHRM1 gene. From top the bottom three figures represent the genotype of CC, CA and AA respectively and the sequenced result of the heterozygote genotype have $\mathrm{C}$ and $\mathrm{A}$ alleles in the same position.

The allele and genotype frequencies in 51 Caucasian Turkish schizophrenic patients are shown in Table 1 for C267A polymorphism in CHRM1 gene. This is the first study to document the frequencies and genotypes of CHRM1 C267A alleles in Turkish patients with schizophrenia. Molecular analyses revealed that, among the 51 patients tested for the C267A genotype, $37(72.5 \%)$ were CC, $13(25.5 \%)$ were CA and $1(2 \%)$ were AA. On the basis of this data, the allele frequency of $\mathrm{C}$ was 0.85 and the frequency for $\mathrm{A}$ was 0.15 . The distribution of CHRM1 genotypes in our samples is presented in Table 1. The $p$ value of present results was $p>0.05$ and it was in good accordance with expected genotype distributions, calculated using the Hardy-Weinberg equilibrium. $\left(\chi^{2}: 0.013 ; p=0.9\right)$.

Table 1. The distribution of the CHRM1 gene polymorphism in Turkish patients with schizophrenia.

\begin{tabular}{|l|l|l|l|l|}
\hline Gene & Genotype & $\begin{array}{l}\text { Observed } \\
\text { Frequency }\end{array}$ & $\begin{array}{l}\text { Expected } \\
\text { Frequency }\end{array}$ & $\begin{array}{l}\text { Allele } \\
\text { Frequencies }\end{array}$ \\
\hline \multirow{3}{*}{ CHRM1 } & CC & 37 & 37.1 & \multirow{2}{*}{ C:0.85 } \\
\cline { 2 - 4 } & CA & 13 & 12.8 & A:0.15 \\
\cline { 2 - 5 } & AA & 1 & 1.1 & \\
\hline
\end{tabular}




\begin{tabular}{|l|l|l|l|l|}
\hline Total & 51 & 51 & 1.00 \\
\hline
\end{tabular}

\section{DISCUSSION}

Due to several gene variations that are potentially involved in physiopathology of mental disorders, CHRM1 C267A polymorphism has a probability to become a genetic biomarker. On the other hand this variation might have a role in psychopharmacotherapy since muscarinic M1 receptor is a prominent target for a considerable number of medications. Three primary objectives were aimed in this study. The main purpose of this study was to develop a novel genotyping assay for CHRM1 C267 polymorphism and to test the accuracy and validity of the developed method. The other two aims were to draw attention to the importance of CHRM1 gene in the pathology of schizophrenia and to determine genotype and allele frequencies of CHRM1 C267 polymorphism in Turkish patients with schizophrenia. M1 receptors could be important for neuronal disorder and cognitive function in the pathophysiology of schizophrenia due to the location in the medial prefrontal cortex and hippocampus. ${ }^{18,19}$ Lower levels of muscarinic receptors in the CNS of people with schizophrenia have been found in some studies. ${ }^{18,20}$ Scarr et al., showed that decreased M1 levels in cortical region of brain could contribute to the pathophysiology of schizophrenia. Thus, a brain imaging test before treatment could be useful in identifying the patients with low M1 levels who could be treatment resistant. ${ }^{21}$ Another neuroimaging study also showed that muscarinic receptors were extensively decreased in schizophrenia patients under treatment during neuroimaging. ${ }^{20}$

At the molecular level, Mancama et al., demonstrated that the levels of CHRMI cDNA was $28 \%$ lower than control group in schizophrenia patients. 22 Moreover, the studies suggested that there could be a relationship between $\mathrm{rs} 2067477$ SNP and reduction in grey matter volume in patients with schizophrenia. ${ }^{23}$ The studies have shown that rs2067477 might be associated with in cognitive performance. In these studies the Wisconsin Card Sorting Test performance which is a measure of prefrontal and executive functions was better in heterozygous individuals than the homozy gous wild-type carriers. ${ }^{17,24}$ In one of these studies, 243 schizophrenic patients were assessed according to the rs2067477 genotype and the genotypes have differed in responses in the Wisconsin Card Sorting Test but not in other parameters including age of onset, chlorpromazine equivalents, and Brief Psychiatric Rating Scale. ${ }^{17}$ Contrary to these, Cropley et al., indicated that homozygous $\mathrm{CC}$ genotype did not have impact on attention, visuospatial-construction, verbal fluency or working memory and they did not assess the patients with Wisconsin Card Sorting Test. ${ }^{23}$ All of these studies showed the importance of the determination of CHRM1 C267A alleles in schizophrenic patients. To the best of our knowledge, this is the first study to document the frequencies of CHRM1 C267A alleles and its genotype distribution in Turkish schizophrenia patients. In this study, genotype distribution and allele frequencies of CHRM1 C267A polymorphism were obtained from 51 Turkish schizophrenia patients. Obtained data were compared with previously reported representative data in other schizophrenia patients as shown in Table 2. Present results showed that the $\mathrm{C}$ and $\mathrm{A}$ allele frequencies in Turkish patients with schizophrenia was 0.85 and 0.15 , respectively. The C267A variant frequency ranges between 0.07- 0.11 in Australian patients with schizophrenia or schizoaffective disorder, while it was found as 0.09 in Chinese schizophrenia patients. ${ }^{17,23-26}$ The difference in frequency of C267A SNP between Turkish schizophrenia patients and other populations patients was not statistically significant $(\mathrm{p}>0.05)$.

Table 2. Genotypes and allele frequencies of C267A SNP in CHRM1 in this study and the other populations.

\begin{tabular}{|l|l|l|l|l|}
\hline Study population & $\mathbf{n}$ & Genotype Frequency n (\%) & $\begin{array}{l}\text { Allele } \\
\text { frequency }\end{array}$ & Reference \\
\hline
\end{tabular}




\begin{tabular}{|l|l|l|l|l|l|l|l|}
\hline $\begin{array}{l}\text { Turkish patients } \\
\text { with schizophrenia }\end{array}$ & 51 & $37(72.5)$ & $13(25.5)$ & $1(2)$ & 0.85 & 0.15 & $\begin{array}{l}\text { Present } \\
\text { study }\end{array}$ \\
\hline $\begin{array}{l}\text { Chinese patients } \\
\text { with schizophrenia }\end{array}$ & 243 & $202(83.1)$ & $40(16.5)$ & $1(0.4)$ & 0.91 & 0.09 & Liao,2003 \\
\hline $\begin{array}{l}\text { Australian patients } \\
\text { with schizophrenia } \\
\text { and schizoaffective } \\
\text { disorder }\end{array}$ & 97 & $83(86)$ & $14(14)$ & - & 0.93 & 0.07 & Scarr et al.,2012 \\
\hline $\begin{array}{l}\text { Australian patients } \\
\text { with schizophrenia } \\
\text { or schizoaffective } \\
\text { disorder }\end{array}$ & 267 & $191(84.1)$ & $35(15.4)$ & $1(0.4)$ & 0.92 & 0.08 & (Cropley et \\
\hline $\begin{array}{l}\text { Australian patients } \\
\text { with schizophrenia } \\
\text { and schizoaffective } \\
\text { disorder }\end{array}$ & 176 & $147(83.5)$ & $29(16.5)$ & - & 0.92 & 0.08 & Carruthers, 2018 \\
\hline $\begin{array}{l}\text { Australian patients } \\
\text { with schizophrenia } \\
\text { and schizoaffective } \\
\text { disorder }\end{array}$ & 147 & $114(77.6)$ & $33(22.4)$ & - & 0.89 & 0.11 & Carruthers, 2019 \\
\hline
\end{tabular}

In summary, a novel, practical, low-cost and reproducible PCR- RFLP method was developed for genotyping the CHRM1 C267A polymorphism. The deyeloped method is based on the elimination of recognition site of Hae III in the forward primer binding site by utilizing a mismatch base in the forward primer. As a result of this study, the validity and accuracy of the present novel method has been proven. Thus, the genotype and allele frequency of CHRMI C267 polymorphism in Turkish patients with schizophrenia has been determined for the first time. The number of samples should be increased in further studies for more certain and reliable results. Additionally, the effect of CHRM1 gene in the pathology and treatment of schizophrenia is explained with the data in the literature. The developed genotyping assay and results could be useful and provide a perspective for future studies.

Financial \& Conflict of interest: This work was supported in part by grant from the Research Fund of Ankara University under Project 18L0217001. The author declares no conflict of interest, financial or otherwise.

Ethical conduct of research: All authors state that the appropriate institutional review board approval had obtained and the informed consent has been obtained from the participants involved study. The authors state that all experiments had followed the principles outlined in the Declaration of Helsinki.

\section{REFERENCES}

1. Howes OD, Murray RM. Schizophrenia: an integrated sociodevelopmental cognitive model. The Lancet. 2014; 383:1677-1687.

2. Owen MJ, Sawa A, Mortensen PB. Schizophrenia. The Lancet. 2016; 388:86-97. 3. Mc Garth J, Saha S, Chant D, Welham J. Schizophrenia: A Concise Overview of Incidence, Prevalence, and Mortality. Epidemiologic Reviews. 2008; 30:67-76.

4. DSM, American Psychiatric Association. Section 2: Diagnotic Criteria and Codes, Schizophrenia Spectrum and Other Psychotic Disorders. In: Diagnostic and Statistical Manual of Mental Disorders, Fifth Edition (5th Ed.). Ed: First MB, Ward MN. American Psychiatric Publishing, Washington, DC. 2013; 99-105. 
5. Saha S, Chant D, Welham J, McGrath J. A systematic review of the prevalence of schizophrenia. PLoS medicine. 2005; 2:413-433.

6. Esan OB, Ojagbemi A, Gureje O. Epidemiology of schizophrenia-An update with a focus on developing countries. International Review of Psychiatry. 2012; 24:387-392.

7. Binbay T, Ulaş H, Elbi H, Alptekin K. The psychosis epidemiology in Turkey: a systematic review on prevalence estimates and admission rates. Turk Psikiyatri Derg. 2011; 22:40-52.

8. Ayano G. Schizophrenia: A Concise Overview of Etiology, Epidemiology Diagnosis and Management: Review of literatures. J Schizophr Res. 2016; 3:1-7.

9. Weiner DM, Meltzer HY, Veinbergs I, Donohue EM, Spalding TA, Smith TT, Mohell N, Harvey SC, Lameh J, Nash N, Vanover KE, Olsson R, Jayathilake K, Lee M, Levey AL, Hacksell U, Burstein ES, Davis RE, Brann MR. The role of M1 muscarinic receptor agonism of $\mathrm{N}$-desmethylclozapine in the unique clinical effects of clozapine.

Psychopharmacology (Berl). 2004; 177:207-216.

10. Scarr E, Cowie TF, Kanellakis S, Sundram S, Pantelis C, Dean B. Decreased cortical muscarinic receptors define a subgroup of subjects with schizophrenia Mol Psychiatry. 2009; 14:1017-1023.

11. Michel MC, Teitsma CA. Polymorphisms in human muscarinic recentor subtype genes. Handb Exp Pharmacol. 2012; 208:49-59.

12. Hamilton SE, Schlador ML, McKinnon LA, Chmelar RS, Nathanson NM. Molecular mechanisms for the regulation of the expression and function of muscarinic acetylcholine receptors. J Physiol Paris. 1998; 92:275-278.

13. Lucas JL, Sadee W, DeYoung JA. Single nucleotide polymorphisms of the human M1 muscarinic acetylcholine receptor gene. AAPS Pharmsci. 2001; 3:57-61.

14. Brann MR, Ellis J, Jorgensen H, Hill-Eubanks D, Jones SV. Muscarinic Acetylcholine-Receptor Subtypes - Localization and Structure-Function. Prog Brain Res. 1993; 98:121-127.

15. APA. DSM-IV-TR: Diagnostic and Statistical Manual of Mental Disorders 4th Revised Edition, American Psychiatric Press Inc. 2000.

16. Miller SA, Dykes DD, Polesky HF. A simple salting out procedure for extracting DNA from human nucleated cells. Nucleic Acid Res. 1988;16:1215.

17. Liao DL, Hong CJ, Chen HM, Chen YE, Le SM, Chang CY, Chen H, Tsai SJ.

Association of muscarinic Ml receptor genetic polymorphisms with psychiatric symptoms and cognitive function in schizophrenic patients. Neuropsychobiology. 2003; 48:72-76.

18. Dean B, MicLeod M, Keriakous D, McKenzie J, Scarr E. Decreased

muscarinic1 receptors in the dorsolateral prefrontal cortex of subjects with schizophrenia. Mol Psychiatry, 2002; 7:1083-1091.

19. Yohn SE, Conn PJ. Positive allosteric modulation of M1 and M4 muscarinic receptors as potential therapeutic treatments for schizophrenia Neuropharmacology. 2018; 136:438-448. 20. Raedler TJ, Knable MB, Jones DW, Urbina RA, Gorey JG, Lee KS, Egan

F, Coppola R, Weinberger DR. In vivo determination of muscarinic acetylcholine receptor availability in schizophrenia. Am J Psychiatry. 2003; 160:118-127.

21. Scarr E, Hopper S, Vos V, Seo MS, Everall IP, Aumann TD, Chana G, Dean B. Low levels of muscarinic M1 receptor-positive neurons in cortical layers III and V in Brodmann areas 9 and 17 from individuals with schizophrenia. J Psychiatry Neurosci. 2018; 43:338-346. 22. Mancama D, Arranz MJ, Landau S, Kerwin R. Reduced expression of the muscarinic 1 receptor cortical subtype in schizophrenia. Am J Med Genet. 2003; 119B:2-6.

23. Cropley VL, Scarr E, Fornito A, Klauser P, Bousman CA, Scott R, Cairns MJ, Tooney PA, Pantelis C, Dean B. The effect of a muscarinic receptor 1 gene variant on grey matter volume in schizophrenia. Psychiatry Res. 2015; 234:182-187. 
24. Scarr E, Sundram S, Deljo A, Cowie TF, Gibbons AS, Juzva S, Mackinnon A, Wood SJ, Testa R, Pantelis C, Dean B. Muscarinic M1 receptor sequence: Preliminary studies on its effects on cognitionand expression. Schizophr Res. 2012;138:94-98.

25. Carruthers SP, Gurvich CT, Cropley VL, Pantelis C, Bousman C, Lenroot

RK, Bruggemann JM, Weickert T; Australian Schizophrenia Research Bank, Rossell SL. The effects of a muscarinic receptor 1 gene variant on cortical thickness and surface area in schizophrenia. Psychiatry Res Neuroimaging. 2018; 280:62-64.

26. Carruthers SP, Cropley V, Bousman C, Everall IP, Neill E, Pantelis C, Sumner PJ, Tan EJ; Australian Schizophrenia Research Bank, Bozaoglu K, Thomas EHX, Van Rheenen TE, Gurvich CT, Rossell SL. The effects of a muscarinic receptor 1 gene variant on executive and non-executive cognition in schizophrenia spectrum disorders. Psychiatry Res. 2019; 273:178-180.

27.

28. 